\title{
MALAPPORTIONMENT AND JUDICIAL POWER
}

\section{THOMAS I. EMERSON}

THE Supreme Court's decision in Baker v. Carr ${ }^{1}$ promises to be one of the most important of the century. Like the segregation decisions, ${ }^{2}$ it brings constitutional principles and judicial institutions to the solution of one of the fundamental problems of American society. Unlike the decisions in the Smith and McCarran Act cases, ${ }^{3}$ which have no future in the democratic process, it moves broadly in the direction of developing and supporting procedures necessary for the effective operation of a modern democratic system. The decision is of interest and significance on various levels. The major ones are (1) its importance in terms of legal doctrine; (2) its bearing on the actual solution of the malapportionment problem; and (3) its broader implications concerning the role of law and legal institutions in the democratic process.

\section{Implications for Legal Doctrine}

The failure of five Justices to agree upon an opinion necessarily limits the significance of Baker v. Carr in doctrinal terms. Moreover, the strong dissent of Justices Frankfurter and Harlan, and the grudging acquiescence of Justices Clark and Stewart, confirmed the close division of the Court over issues of the sort presented. The retirement of Justices Whittaker and Frankfurter, and their replacement by Justices White and Goldberg, whose constitutional views have not yet become apparent, makes speculation on the Court's future direction additionally hazardous. Nevertheless, the decision in Baker v. Carr does throw some light upon possible developments in the three main legal doctrines raised in the case: equal protection, justiciability, and the guaranty clause.

In applying the broad constitutional requirement of equal protection of the laws, the Supreme Court has, with a few sharp exceptions, moved with the utmost caution. The chief exception is, of course, in the area of racial discrimination. Here the Court, at least since Brozen v. Board of Education, has enforced the provision vigorously, even when necessary to extend the doctrine of "state action" to unprecedented and still unforeseen lengths. ${ }^{4}$ It has also invoked the principle in the field of criminal procedure, as evidenced by its line of decisions requiring the states to afford equal opportunity for indigent de-

†Lines Professor of Law, Yale Law School.

This article, with certain additions, is being published simultancously in Lane in Transition.

1. 369 U.S. 186 (1962).

2. Brown v. Board of Education, 347 U.S. 483 (1954), 349 U.S. 294 (1955).

3. Dennis v. United States, 341 U.S. 494 (1951). See also, Scales v. United States, 367 U.S. 203 (1961) ; Communist Party v. Subversive Activities Control Board, 367 U.S. 1 (1961).

4. Brown v. Board of Education, 347 U.S. 483 (1954); Burton v. Wilmington Parking Authority, 365 U.S. 715 (1961). 
fendants to invoke facilities for appeal. ${ }^{5}$ Beyond these limited sectors, however, the Court has traditionally been extremely reluctant to set foot in what has seemed to it the bottomless quagmire of equal protection. ${ }^{\circ}$ All government action involves discrimination between persons affected and those not affected, or between those affected in certain ways and those affected in others. To separate the appropriate from the inappropriate differences in treatment has undoubtedly appeared a dubious exercise in judicial supervision from which the Court has naturally shrunk. Yet the requirement of equal protection of the laws constitutes a fundamental principle of a democratic society, and one more subject to disregard or violation as government controls over society expand. It remains one of the few areas where the courts can legitimately exercise some degree of control over the substantive results of the working of the democratic process. Narrower than substantive due process, which the courts have, quite properly, largely abandoned, an increased supervision over equality of treatment by the state in exercising its manifold powers could become a vital function of our judicial system.

In Baker v. Carr a majority of the Court did not, of course, officially reach the merits and hence did not treat the application of the equal protection clause to apportionment cases. But it held that the clause was applicable, in that a "substantial question" was raised under it. ${ }^{7}$ And the plain implication of the decision was that an apportionment as seriously distorted as that of Tennessee was most likely a violation of equal protection. Despite the enormously difficult problem of working out standards for utilizing the equal protection provision in apportionment cases-a difficulty the dissenters played to the hilt-the majority felt impelled to enter the field. And, just as in the race discrimination cases the Court found it necessary to give a wholly new meaning to "state action," so here it was not deterred by the novel and dangerous problem of fashioning adequate relief. The fact that the Court was dealing with the right to vote, a fundamental and special area, indicates that one should perhaps not make too much of this new use of the equal protection clause. Yet the decision does suggest that the concept of equal protection may well in the future receive increased attention in its application to other aspects of our national life.

With respect to the justiciability doctrine, the fact that the Court agreed to decide the apportionment issue is in itself momentous. For it did so in the face of the violently partisan nature of the problem, the elusiveness of standards, the possible repudiation of judicial efforts to frame a remedy, the long line of contrary decisions behind which it could have hidden ${ }^{8}$ and much scholarly advice

5. Griffin v. Illinois, 351 U.S. 12 (1956). See also Smith v. Bennett, 365 U.S. 708 (1961) ; Burns v. Ohio, 360 U.S. 252 (1959) ; Eskridge v. Washington Bd. of Prison Terms \& Paroles, 357 U.S. 214 (1958).

6. See, e.g., McGowan v. Maryland, 366 U.S. 420 (1961) ; Salsburg v. Mfaryland, 346 U.S. 545 (1954) ; Goesaert v. Cleary, 335 U.S. 464 (1948) ; Kotch v. Board of River Port Pilot Comm'rs, 330 U.S. 552 (1947). But cf. Morey v. Doud, 354 U.S. 457 (1957).

7. 369 U.S. at $198-204$.

8. Colegrove v. Green, 328 U.S. 549 (1946), and following cases, discussed 369 U.S. at 234-37. 
to stick to the "passive virtues." Plainly, the realm of non-justiciability has been narrowed. It will not be quite the same again.

More specifically, the Court's treatment of the "political question" is likely to result in some crystalization and confining of that amorphous concept. Mr. Justice Brennan's opinion first eliminates from coverage of the doctrine all matters concerning "the federal judiciary's relationship to the States," liniting it to "the relationship between the judiciary and the coordinate branches of the Federal Government. ..."10 It then rejects blanket application of the doctrine to any broad areas of categories of cases, such as "[f] oreign relations," "[d]ates of duration of hostilities," validity of procedures in enacting constitutional amendments or statutes, and "[t]he status of Indian tribes."11 To the contrary, it stresses "the need for case-by-case inquiry," "the necessity for discriminating inquiry into the precise facts and posture of the particular case, and the impossibility of resolution by any semantic cataloguing."12 Further, the opinion goes on to enumerate the specific elements which make an isste into a "political question."13 There is a strong implication that the list given is exclusive. But even if not, the listing compresses the doctrine into a far more rigid form. Hereafter litigants will not be faced with a completely open-ended concept, but will have the opportunity to argue their way out of each individual element. It is to be noted that Justices Clark and Stewart did not question these features of the Brennan opinion, and that Mr. Justice Douglas went beyond.

The Court's handling of the "political question" issue thus has significant implications in other areas. For example, it may well prove important in stch matters as the Court's function in dealing with state attempts to invoke martial law, provided no head-on clash between the Court and Congress or the President is involved. Similarly, it may even open up such questions as federal court enforcement of section 2 of the fourteenth amendment, providing for reduction in the congressional representation of states which deny their citizens the right to vote. ${ }^{14}$

Less surely, but potentially of more importance, the decision in Bakar v. Carr may have significance in the Court's future treatment of the guaranty clause. The provision in article IV, section 4, guaranteeing each state a republican form of government, was originally designed as a basic feature of our constitutional structure. It was intended to mean more than that the federal government had the power and duty to protect the states against insurrection or invasion, for these protections were included in the same section as separate

9. See Bickel, The Supreme Court, 1960 Term-Foreword: The Passive Virtues, 75 HaRv. L. REv. 40 (1961).

10. 369 U.S. at 210.

11. 369 U.S. at 211-17.

12. 369 U.S. at $210-11,217$.

13. Summarized in 369 U.S. at 217.

14. See Bonfield, The Right to Vote and Judicial Enforcement of Section Two of the Fourteenth Antendment, 46 CORNELL L.Q. 108 (1960). 
guaranties. At the time of Dorr's Rebellion in 1841-42 the guaranty clause was invoked as the basis for a claim which would have required the Supreme Court to decide which one of two competing Rhode Island governments was the legitimate one. In Luther $v$. Borden, ${ }^{15}$ however, the Court held, in a sweeping opinion, that this issue was non-justiciable. The guaranty clause was utilized after the Civil War as the major constitutional basis for the program of Reconstruction enacted by Congress. But in the following decades the guaranty clause became in practice largely superseded by the fourteenth amendment. In 1912, in Pacific States Tel. \& Tel. Co. v. Oregon, ${ }^{10}$ the guaranty clause was relied upon as a ground for arguing that the Oregon initiative and referendum law was invalid as inconsistent with a republican form of government. The Court, again in a broad opinion, held this issue non-justiciable. Since then the traditional rule has been that all claims presented to the Court under the guaranty clause are non-justiciable. ${ }^{17}$

Mr. Justice Brennan purported to leave guaranty clause doctrine unchanged. But his treatment of the issue may in fact have reopened the question. The Brennan opinion does not take the position that the guaranty clause is to be interpreted as vesting enforcement only in Congress or the Executive. On the contrary, it expressly states that the sole reason the guaranty clause is not enforceable by the courts is that the issues raised under it are "political questions."18 Mr. Justice Frankfurter agreed. ${ }^{10}$ But since Mr. Justice Brennan repudiates the notion that "political questions" are to be determined by blanket categories and makes clear that each case must be determined on its own facts, it would seem that the issue of justiciability under the guaranty clause would likewise turn on whether the essential elements of a "political question" are present in any particular case. Furthermore, Mr. Justice Brennan concedes that a question of republican form of government does not always become a political one by reason of "the lack of criteria" for judgment.." Once these two objections are eliminated, it is hard to see why the Court should not treat questions under the guaranty clause the same as other alleged "political ques-

15. 48 U.S. (7 How.) 1 (1849).

16. 223 U.S. 118 (1912).

17. The rule presumably does not mean that action taken by Congress or the President upon the basis of the guaranty clause is not subject to any review whatever by the courts; this would allow the legislative and executive branches, through the mere formality of invoking the clause, to evade judicial review and, in fact, would come close to destroying the whole institution of judicial review. Indeed, in Coyle v. Smith, 221 U.S. 559 (1911), the Supreme Court held unconstitutional an attempt by Congress, relying on the guaranty clause, to specify the location of Oklahoma's capital as a condition of admission to the Union. See also 369 U.S. at 226 n.53. But the extent of review by the Supreme Court over the exercise of power by the other branches in reliance on the guaranty clause has never been clarified.

For an historical account of the guaranty clause, see Bonfield, The Guaraustec Clanse of Article IV, Section 4: A Study in Coustitutional Destelude, 46 Mfrws. L. Rev. 513 (1962).

18. 369 U.S. at $218,228-29$.

19. 369 U.S. at 297.

20. 369 U.S. at $222-23$ n.48. 
tions." On this view, the Court would hold guaranty clause cases non-justiciable only where a decision would involve a direct clash with Congress or the President, or involve one of the other elements of a "political question" listed by Mr. Justice Brennan. Clearly Mr. Justice Brennan did not draw this conclusion. But it seems implicit in his analysis. The other Justices forming the majority did not challenge this approach. And Mr. Justice Douglas was obviously thinking in these terms. ${ }^{21}$

For these reasons it appears possible that the Court might in the future consider apportionment issues under the guaranty clause. As we argue later, there would be many advantages in doing so. Beyond this, were the Court to entertain claims under the guaranty clause, in cases where none of the Brennan elements of a "political question" were present, it would open up an important new line of constitutional growth. While the original purpose of the guaranty clause was primarily to assure that the states did not take on an aristocratic, monarchistic, or despotic form of government, the interpretation of republican form of government in the light of modern developments would extend the application of the provision to numerous significant areas. Thus, isstes such as the closing of public schools might be dealt with in terms of maintaining a republican form of government. Such a development of constitutional doctrine would be entirely consistent with the Court's current role as an institution for supporting and vitalizing the mechanisms of the democratic process without undertaking to supervise the results reached by that process. ${ }^{22}$

\section{Extent of Solution of the Apportionament Problems}

What does Baker v. Carr portend as to the Supreme Court's handling of the apportionment problem when it reaches the merits? Will the Court confine itself to certain kinds of cases? What standards will it apply in determining the validity of an apportionment system? What will be the nature of the remedy decreed? And to what extent is judicial action likely to solve or allevinte the basic problem?

It would be foolhardy to attempt detailed answers to these questions. No one is now in possession of all the facts. The issues are varied and complex; many cannot now be clearly defined or anticipated. The degree to which state political machinery is capable of reforming itself cannot be known. Public response, and hence the effective power of the Supreme Court, is not fully foreseeable. The ultimate solution, if one is ever completely achieved, must be hammered out by a long process of discussion and compromise in accordance with the democratic tradition. At most, therefore, it is possible to note some of the major issues, consider some tentative solutions, and perhaps inclicate the general direction of events.

21. 369 U.S. at 242-43 n.2. For an elaboration of this argument, see Bonficld, Baker v. Carr: Newe Light on the Guarantee of Republican Government, 50 CAur. L. REv. 245, 246-52 (1962). $560-69$.

22. On the current potential of the guaranty clause, see Bonfield, supra note 17 , at 


\section{A. Types of Situations Open to Judicial Consideration}

Baker v. Carr involved (1) state legislative districts; (2) state constitutional provisions basing apportionment in both houses roughly on equal population, the apportionment to be made by the legislature on a decennial basis; (3) failure by the legislature to reapportion over a long period of years; and (4) no available method, other than action by the legislature, by which the constitutional mandate could be carried out. There is nothing in the decision to indicate, however, that a justiciable constitutional cause of action will be found only where all these elements are present.

The two other situations in which a claimed malapportionment of state legislative districts might occur would clearly seem to fall within the principles enunciated by the decision. Where the asserted inequality arises from affirmative action of the legislature, rather than failure to act, the case for judicial review would appear even more plain. Indeed, here the problem of devising a remedy may be less difficult. Where the state constitution itself creates the alleged malapportionment-the so-called de jure case-no additional theoretical problems are presented. It is immaterial whether state action denying equal protection derives from statutory or constitutional sources. And, while the framing of a remedy might be more troublesome, it is unlikely that such diffculties would be sufficiently greater to alter the Court's position. The remand of the Michigan and New York cases indicates that the de jure situation will also reach decision on the merits. ${ }^{23}$

With regard to inequality in congressional districts, there is language in the Brennan opinion which might suggest that Baker v. Carr is not decisive on the issue of justiciability. As already mentioned, the opinion takes pains to point out that the doctrine of "political questions" does not apply to relations of the federal courts to the states, but rather is a matter of the relationships between the coordinate branches of the federal government. ${ }^{\text {at }}$ And in the case of congressional districts, Congress enters the picture under its power to determine the qualifications and supervise the election of its own members. Yet it seems most unlikely that the Supreme Court will refuse to entertain cases of this nature. The possibility of open conflict with Congress is remote. Practical remedies, as will be seen shortly, are more readily available. Colegrove $v$. Green, ${ }^{25}$ the main obstacle to the Court's new position, was not distinguished on this ground. Moreover, the momentum engendered by Baker v. Carr would seem to assure that the Court will not go out of its way to create distinctions that would in practice appear entirely artificial, imposing greater restrictions on districting state legislative seats than congressional seats. Finally, Mr. Justice Brennan expressly declared, speaking for three members of the Court, that prior cases "settled the issue in favor of justiciability of questions of congressional redistricting." 26

23. WMCA, Inc. v. Simon, 370 U.S. 190 (1962); Scholle v. Hare, 369 U.S. 429 (1962).

24. See text at note 10 supra.

- 25. 328 U.S. 549 (1946).

26. 369 U.S. at 232. But cf. Wesberry v. Vandiver, 206 F. Supp. 276 (N.D. Ga. 1962) (đismissing a congressional district case). 
Nor does there seem to be any doubt that the principles of Baker $v$. Carr are applicable to primary elections. Under the Classic case and the white primary cases primaries are treated as integral parts of the election process and equally subject to the requirements of the fourteenth amendment. ${ }^{27}$

There remain for consideration those situations in which a remedy other than through action of the state legislature itself might be available. In the few states where statutes provide for apportionment by administrative commission or similar device, the Supreme Court will undoubtedly insist upon exhaustion of state administrative remedies before federal relief can be sought. And in certain cases where doubtful questions of interpretation of state constitutional provisions are involved, the Court might require state judicial remedies to be pursued. Otherwise, there would appear to be little justification for the Court to refuse consideration of the merits on the ground that other remedies are available. Individual rights accruing under the equal protection clause are not normally dependent upon exhaustion of state judicial remedies. Relief by way of initiative and referendum laws, available in some states, is too cumbersome and uncertain to serve as the basis of any doctrine of exhaustion. The difficulty under such procedures of framing a detailed constitutional amendment or statute acceptable to a majority of voters, the lack of opportunity for amending or compromising the initial proposal, the effort and expense of collecting a large number of valid signatures, and similar inflexibilities and technicalities render such devices of dubious practicality. ${ }^{28}$ Similar considerations apply to state constitutional provisions for popular initiative in calling a constitutional convention. It is to be noted that only Mr. Justice Clark put any stress on the absence of other forms of relief. At most the existence of such devices might be one factor to be considered in determining whether to afford discretionary equitable relief; it should scarcely be decisive of the isstic.

In sum, it would seem that Baker $v$. Carr has opened to judicial consideration all aspects of the malapportionment problem, regardless of the source of the claimed inequality.

\section{B. Standards}

The formulation of "judicially manageable" standards for decision of future cases on the merits poses a difficult and intriguing problem. The majority in Baker v. Carr did not undertake to solve it, and those Justices who discussed the question were in agreement only on the proposition that the equal protection clause prohibits "invidious discrimination." Efforts by lower courts and commentators to work out an acceptable formula have not progressed very far. The issue will yield to solution only on a case-by-case basis.

27. United States v. Classic, 313 U.S. 299 (1941); Terry v. Adams, 345 U.S. 461 (1953).

28. See, for example, the problems of securing relief through the initiative in Oklinhoma, recited in the amicus brief filed by the Governor of Oklahoma in Balier v. Carr, at pp. 14-17. 
Certain aspects of the problem, however, would not appear too difficult. In a case, such as Baker v. Carr itself, where the state constitution provides for legislative districts of roughly equal population, either in both houses or only one, the failure by the legislature to maintain such districts would constitute a classic form of denial of equal protection. The case would be no different from any other in which state officials administered state law on a discriminatory basis. ${ }^{29}$ The standard for complying with the equal protection clause would therefore be the creation of legislative districts consisting of substantially equal number of voters. Variations by reason of observing county lines, handling fractions, and the like would exist, but only to the extent necessary to meet practical problems. According to expert estimates such variations should not exceed ten to fifteen per cent. In a case of this nature, in short, there is no reason why the Supreme Court should not require the state to adhere to the basic requirements of the state constitution. ${ }^{30}$

The standard applicable to congressional districting would likewise not appear to involve any great difficulty. The federal constitution, particularly in providing that members of the House of Representatives are to be elected by "the People of the several States," would not seem to contemplate that in choosing such representatives the vote of one qualified citizen should carry substantially less weight than that of another. ${ }^{31}$ Certainly it is the general expectation that congressional districts be formed of roughly equal population. The Supreme Court may therefore properly hold that the creation of congressional districts of unequal voting strength constitutes a denial of equal protection. And the standard for measuring adherence to this constitutional requirement is simply that the districts be, within practical limits, equal in population.

Once the Court gets involved beyond this point, however, the difficulties increase. When the state constitution, or the state legislature acting within the state constitution, takes into account factors other than population, the problem of deciding when the inequality in terms of numbers becomes so egregious as to outweigh the value of the other factors, thereby becoming "invidious discrimination," is not easily answered.

At the outset, one must ask the question whether this problem is not better conceived as an issue of republican form of government than of equal protection. There is much force in Mr. Justice Frankfurter's argument that equal protection implies some basic standard from which to measure deviation, and that the determination of this standard is essentially a question of republican

29. See, e.g., Snowder v. Hughes, 321 U.S. 1 (1944).

30. Justices Frankfurter and Harlan argued in Baker v. Carr that the fact that the Tennessee apportionment was in violation of the Tennessee Constitution did not in itself constitute a violation of the equal protection clause. 369 U.S. at 325-27, 332. It is difficult to follow this reasoning. It is true that a state constitutional provision creating unequal districts might violate equal protection, just as a statute would, and in this sense the distinction between constitution and statute is immaterial. But it does not follow that a statute denying rights established by the state constitution might not constitute a separate and different violation of the equal protection clause.

31. Art. I, § 2. 
form of government. ${ }^{32}$ In any event there can be little doubt that the Court, in seeking a solution of the apportionment problem, will actually be thinking in terms of republican form of government. That concept is indeed well designed for coping with the question. Historically the idea of a republican form of government was closely tied in with the system of legislative representation; it has become even more so today as the right to the franchise has widened. On the other hand, the equal protection requirement is limited by the doctrine that the state is entitled to make a "reasonable classification." But, as Mr. Justice Harlan comes close to showing, the application of "reasonable classification" is hardly adequate to solve the apportionment problem and, in this area, will have to be badly strained or abandoned. Thus the republican form of government concept is both more relevant and more precise. It would certainly serve as a better vehicle through which the Court could articulate and justify its conclusions. ${ }^{33}$

The Court may well, however, hesitate to add to its burdens by making such a seemingly radical departure as to revive the guaranty clause. And it must be admitted that all that it needs, or possibly wants, to do can be crammed within the formula of "invidious discrimination." We must therefore examine the problem on the assumption that the Court adheres to the equal protection formulation.

It has been urged that the Court, in applying the equal protection clatse, should rule out all factors which have the effect of creating any substantial deviation from a system of legislative districts consisting of equal population. This position has been taken by the American Civil Liberties Union. ${ }^{34}$ There is much to be said in its favor. When one comes to examine the factors other than population-and there are actually far fewer than the "host" of which Mr. Justice Frankfurter speaks-the argument for giving them weight in a modern system of state apportionment is far from persuasive. The major ones are recognition of political subdivisions, weight according to density of population, representation of various communities of interest, and historical factors. Others, such as stability of the apportionment system, retaining honored incumbents, and the like are purely secondary. It is not possible here to analyze these various factors in detail but serious questions can be raised as to their value in outweighing the right of each citizen to an equal vote in electing his state legislature.

Thus, recognition of political subdivisions is not a matter of first importance today in the internal affairs of a state. There is no real analogy here to the position of the states at the time of framing the federal constitution, when claims of sovereignty forced acceptance of a system of two Senators from ench state. Moreover, subdivisional lines can be respected without unduly distorting the voting population of the districts, provided there is no requirement that

32. 369 U.S. at 299-301.

33. For further elaboration of the argument, see the two Bonfield articles, supra notes 17 and 21.

34. American Civil Liberties Union Weekly Bulletin, Mar. 20, 1961, pp. 1-2. 
each subdivision have a whole vote. The argument for giving greater weight to areas of thin population is that density of population gives an advantage in political organization. But the revolution in transportation and communication, and the phenomenal growth of organization generally, have radically altered this situation. Indeed, it can be argued that social pressures leading to political cohesion are more likely to be found in rural than urban areas, and that legislators representing the steady clientele of rural areas have advantages over their colleagues representing more volatile urban constituencies. The theory that any particular "community of interest" should be given greater representation in the state legislature than its numbers entitle it to is essentially inconsistent with our notions of democratic process. The theory is little more than a throwback to the days of property-holding qualifications on the right to vote. The advantages of veto power potential and protection of minority rights are afforded through other features of our political system. The historical argument, developed at great length by Mr. Justice Frankfurter, is at first sight impressive. But actually it proves too much, for it assumes the validity of political ideas and practices long since repudiated. The historical trend has been entirely in favor of equality of the franchise.

It will be urged that considerations of this nature are matters of policy for legislatures and the framers of constitutional amendments, not for courts. This is in part true. And it is perhaps doubtful that such arguments, even if fuily supported by empirical evidence, will persuade the Supreme Court in the near future to establish a standard of equal protection based upon voting population alone. Nevertheless, it is relevant to the Court's function that the argument for representation founded upon such other factors is a dubious one. For, as we point out later, unless the Court adopts some mechanical formula of allowable deviation in apportionment cases, it will be forced into some consideration of the validity and weight of the reasons offered for qualifying the underlying right to equality in voting. If the propositions here advanced are sound, the Court should at least scrutinize non-population factors with care and require proponents of such a system to establish their case with precision. To this extent the doctrine that the burden of establishing unconstitutionality rests upon those challenging the legislative classification should be modified.

If we turn to less speculative matters, the problem still remains of giving some content to the test of "invidious discrimination." It seems clear that the Court will not adopt Mr. Justice Harlan's rule of a scintilla of rationality. ${ }^{35}$ As Mr. Justice Harlan himself demonstrates, such a doctrine would never, or hardly ever, result in a decision that the equal protection clause had been violated. It is likewise very doubtful that a majority of the Court will accept Mr. Justice Clark's "crazy quilt"36 principle, or even the "without-any-possiblejustification-in-rationality" formula ${ }^{37}$ of Mr. Justice Stewart. Such approaches do not go very far toward solving the problem, and the Court seems committed

35. 369 U.S. at $336-37,345-49$.

36. Id. at 254 .

37. Id. at 265 . 
at least to making a serious attempt. Rather, it is more likely that the Court will look at the situation in terms of whether or not factors other than population operate so as unduly to subordinate the basic right to equality in exercising the franchise.

What, in practice, would the adoption of some such intermediate formula mean? In the first place, the Court should refuse to legitimize all factors that are non-democratic in character. Thus an apportionment system based on racial factors would clearly constitute a denial of equal protection. On the same theory the New Hampshire system, under which senatorial districts are formed in accordance with the proportion of direct taxes paid, i.e., on the basis of wealth, would appear vulnerable. ${ }^{38}$ Very likely an attempted justification for giving special weight to particular economic or other interests would fall within the same ban.

Secondly, the Court might accept the proposition that at least one house of the legislature must be apportioned on an equal population basis. This is the federal system. All but eleven states, at least in theory, now substantially meet this requirement. ${ }^{39}$ And the average citizen would certainly feel that a system in which neither house was elected on a one-man, one-vote basis could not be reconciled with equal protection of the laws.

Yet, if the Court stopped here, the apportionment problem would still be far from settled. It would give a majority of voters a veto power, but it would not assure them legislative strength to take affirmative action. The crucial issue, therefore, becomes how far would deviations from a population basis be allowed in the second house. There is probably substantial agreement on the chief elements to be considered in measuring the extent of deviation. They are (1) the proportion of the total voters who are able to elect a majority of the representatives to that house; and (2) the relative value of a vote in the larger districts as compared with the smaller ones, measured either by direct comparison or by comparison with an average. But there is no agreement on the formula for determining at what point these discrepancies are sufficiently great to violate the equal protection clause.

Various standards have been proposed. In the Georgia county unit case the three-judge court formulated the rule that the discrepancy existing with respect to any county would be valid if no greater than "the disparity that exists against any state in the most recent electoral college allocation, or under the equal proportions formula for representation of the several states in the Congress. . . "40 This formula would apparently make the Georgia county unit system untenable. ${ }^{41} \mathrm{Mr}$. Bonfield has suggested that deviation in the first element mentioned above should not exceed that existing at the time of entry of the state into the Union, or that suffered by any state through its repre-

38. N.H. Const. pt. 2, art. 26.

39. See Baker, State Constitutions: Reapportionment 5-8, $63-70$ (1960).

40. Sanders v. Gray, 203 F. Supp. 158, 170 (N.D. Ga. 1962).

41. N.Y. Times, June 19, 1962, p. 1, col. 2 . 
sentation in the United States Senate, whichever standard is higher.? The test of Senate representation would invalidate all state systems in which less than 16.5 per cent of the voters elected a majority of representatives; the historical test would vary with each state but generally would call for more equality than presently exists. A further possibility is that the Court simply accept some fixed percentage of deviation as permissible or impermissible. ${ }^{13}$

It is doubtful that the Supreme Court will accept rigid standards of this nature. If it does not, then it must undertake a more thorough exploration of the merits of each case. It would have to take into account all relevant factors, including the claimed justification for deviations from equal population, and render a general verdict as to whether the system does or does not unduly subordinate equality of voting power. Eventually such a method may come to form a pattern which can be generalized into a more specific standard. Under such an approach, much will depend upon the extent to which the Court is willing to scrutinize the justifications advanced in support of deviations. If the conclusion stated above is correct, that such justifications are not persuasive, the trend of decision would be strongly in the direction of an equal population standard.44

It should be noted that the Court's difficulties in devising a standard could be lightened by congressional assistance. The power of Congress to provide specific standards for the creation of congressional districts would not seem open to question. And under the guaranty clause, ${ }^{45}$ Congress could also frame standards for state legislative districting. There would be some advantages in action by Congress to this end, for it would permit fuller consideration of policy issues in devising standards and place the prestige of the federal legislature behind the Court's effort to solve the apportionment problem. Yet the difficulties of formulating adequate standards to cover the varied systems of state legislative apportionment would still remain. And divergence between congressional and judicial views would give rise to still further problems.

\section{Remedies}

The greatest danger facing the courts in dealing with the question of remedies has been that legislative or executive officials would refuse to comply with

42. Bonfield, sipra note 21 , at 257-62.

43. See, e.g., Scholle v. Hare on remand, in which two of the four majority justices said: "When a legislative apportionment provides districts having more tharr double the population of others, the constitutional range of discretion is violated." 367 Afich. 176, -, 116 N.W.2d 350, 355 (1962).

44. We do not here undertake to consider the standard that would be applicable in cases where the populations of voting districts are roughly equal but with district lines gerrymandered to the advantage of one political party. The problems overlap because the professed desire to achieve equal population could be used as a device to achieve an invidious gerrymander. The factors to be taken into account in formulating a standard for dealing with this type of manipulation, however, are somewhat different from those relevant to the equal population issue.

45. U.S, CoNST, art. IV, § 4. 
remedial decrees. The spectre of open conflict between the courts, "possessed neither of the purse nor the sword," and officials of other branches, fired with partisan zeal and threatened in their very political existence, has continually haunted the judiciary. Actually, these fears have proved groundless. Such conflict did not occur in situations where state courts, before Baker v. Carr, undertook to formulate a remedy. ${ }^{46}$ And there has been no sign of this sort of opposi" tion in the many cases that have already followed Baker $v$. Carr. ${ }^{47}$ In contrast to the hostile response which greeted the segregation decisions in the South, the apportionment decision has met with general support throughout the country and, indeed, has proved to be a highly popular one. The pattern of acceptance thus far demonstrated is likely to become more deeply rooted as time passes and the role of the courts becomes more permanently fixed. In this context the problem of remedies, if not simple, by no means appears insoluble.

Mr. Justice Clark, in his opinion in Baker v. Carr, objected to federal courts' assuming jurisdiction of reapportionment cases "in the hope that such a declara" tion, as is made today, [would] have the direct effect of bringing on legislative action and relieving the courts of the problem of fashioning relief"; in his view "this would be nothing less than blackjacking the Assembly into reapportioning the State." 48 Yet something of this sort must necessarily be a court's initial step. A declaratory judgment or an opinion holding the existing system invalid, with postponement of further decree until the legislature can act, wottd normally be the court's opening move. Such a procedure has the advantage of placing the burden of affirmative action where it belongs, on the legislative or constitutional amending process, and reserving to the court the veto, modifying and approving function. The possibility of delay is not the all-important factor here that it may be in other types of litigation. And the court, by retaining jurisdiction, can act quickly to render a decision on the validity of the modified system. Many of the district courts confronted with the problem of remedies in the flood of litigation after Baker $v$. Carr have adopted this approach, including those in Florida, Colorado, Georgia, Pennsylvania, and in the Tennessee case itself on remand. ${ }^{40}$

In this connection, an important issue may be whether modification of a system based on the state constitution can be undertaken by the legislature. The

46. See, e.g., Lewis, Legislative Apportionment and the Federal Courts, 71 HAnv. L. Rev. 1057, 1066-70, 1087-90 (1958) ; 369 U.S. at 250 n.5.

47. For discussion of the cases up to the first week of September, see Goldberg, Thic Statistics of Malapportionment, 72 Yale L.J. 90 (1962). The best source of information concerning current cases is the National Municipal League, 47 East 68 St., New York 21, N.Y.

48. 369 U.S. at 260.

49. Sobel v. Adams, Civ. No. 182-62-M, S.D. Fla., decided July 23, 1962; Stein v. General Assembly of Colorado, No. 20240, Sup. Ct. of Colo., decided July 9, 1962; Toonibs v. Fortson, 205 F. Supp. 248 (N.D. Ga. 1962) ; Butcher v. Trimarchi, No. 2431, Equity, No. 151, Commonwealth Docket, Court of Common Pleas, Dauphin County, Pa., decided June 13, 1962; Baker v. Carr, 206 F. Supp. 341 (M.D. Tenn. 1962). For more details on these cases see Goldberg, supra note 47. 
amending process is, in some states, an elaborate one which may take several years to complete. In such circumstances, however, there would seem to be no constitutional reason why the legislature could not, at least temporarily, change the system to meet federal constitutional requirements, pending action by the more time-consuming procedures of amendment.

In order for the initial judicial step to be successful, forcing the job of framing a valid system on the legislature, it is necessary that the court have in reserve some positive form of action which renders its "threat" plausible and exerts the requisite pressure on the legislature to act. Perhaps the most effective instrument for this purpose is the power of the court to order an electionat-large. In the case of congressional districts this weapon is a readily administerable one. The same is true in the county-unit cases, and in fact the district court has already compelled an election-at-large for governor in Georgia." Where the issue concerns state legislative districts, the use of the election-atlarge raises more troublesome problems. But as a temporary measure it is entirely feasible, particularly if only one house is involved. The prospect of an election-at-large, in any of these situations, is bound to exert enormous pressure to effectuate a valid apportionment. The forces at work in local machine politics, the expense to local candidates of state-wide elections, the possibility of defeat for the political interests opposing reapportionment (by definition likely to be a minority), and other factors all tend in this direction. The technique of ordering an election-at-large is readily enforceable by decrees directed against state election officials in charge.

The major alternative open to the court, either as a means of forcing action by other institutions of government or as directly resolving the problem, is for the court itself to frame the changes necessary in the apportionment system. In earlier discussion of the problem the notion that a court would affirmatively undertake the task of reapportionment was virtually inconceivable. Mr. Justice Frankfurter reflected this climate of opinion when he observed, "Surcly a Federal District Court could not itself remap the State. . .."31 But thinking on the subject has moved with unexpected rapidity. Mr. Justice Clark's concurrence, otherwise not of a radical bent, suggested such a solution. And it has already been utilized by courts in Alabama and Mississippi. ${ }^{\text {to }}$ To the degree

50. Sanders v. Gray, 203 F. Supp. 158 (N.D. Ga. 1962). Cf. N.Y. Times, Sept. 13, 1962, p. 21, col. 4.

A lower court in Kansas has likewise ordered state-wide elections. See Goldberg, supra note 47 , at $98 \mathrm{n} .42$.

51. 369 U.S. at 328 .

52. Sims v. Frink, 205 F. Supp. 245 (M.D. Ala. 1962) ; Fortner v. Barnett, No. 59,965, Chancery Court, First Judicial District, Hinds County, Miss., decided June 7, 1962. Cf. Wisconsin v. Zimmerman, Civ. No. 3540, W.D. Wis., July 3 \& Aug. 14, 1962. In the latter case the court appointed a master to draw the reapportionment plan. After hearings, the master recommended dismissal without prejudice to further action after the 1962 elections, a recommendation accepted by the court. See N.Y. Times, July 4, 1962, p. 1, col. 2; July 26, 1962, p. 24, col. 8; Aug. 6, 1962, p. 22, col. 3. See Goldberg, stipra note 47, at 95. 
that the standard of equal protection approaches one of equal poptlation the feasibility of this form of remedy increases.

Beyond these methods there are other possibilities available. One is for the court to enjoin election officials in particular counties from conducting an election in which more than a specific number of representatives are to be elected. Another is for the court to act only with respect to one house, retaining jurisdiction as to the other. More radical is the proposal that the court permit elections as before but order a system of weighted voting in the legislatture, a favorite device of some political scientists. Other improvisations are possible to fit the particular case. The courts will certainly retain flexibility in devising an appropriate remedy. ${ }^{53}$

All in all, then, the problem of remedies does not seem as difficult of solution as originally appeared. Indeed, the normally rigid judicial process seems about to yield to innovation and ingenuity. Such a development would be in line with the recent expansion of judicial techniques in some other areas, such as the administration of anti-trust decrees and of pupil assignment laws.

\section{The General Prospects for Judicial Solution}

When the decision in Baker v. Carr came down, perceptive analysts were careful to point out that the case decided only that the federal courts had jurisdiction in apportionment matters and that the extent to which the courts would acually do something about the apportionment problem was a question for the uncertain future. $^{54}$ This warning must still be heeded. Yet an appraisal of the situation in light of the above analysis, and particularly in light of developments since the original decision, indicates that the prospects for substantial reform are bright. The decision certainly opens up all forms of malapportionment to judicial scrutiny. Much will depend upon whether the standards of equal protection adopted move in the direction of assuring one house fully, and the other substantially, apportioned on an equal poptlation basis. For the reasons already given, this should be the trend of decision. The problem of devising effective remedies can be solved. Popular response has been most favorable. And, in the cases already brought in more than thirty states, judicial response has on the whole been aggressive. But the ultimate outcome, of course, remains uncertain.

\section{The Role of Law and Legal Institutions}

It will have become clear by now that the main significance of the decision in Baker v. Carr lies not in what was actually decided, or in what was expressly

53. It has been assumed, probably with justification, that state election laws may be modified by judicial decree in order to conform to constitutional requirements.

54. See, e.g., Lewis, "Decision on Reapportionment Points Up Urban-Rural Struggle," N.Y. Times, April 1, 1962, § IV, p. 3; Bickel, "The Great Apportionment Case," New Republic, April 9, 1962, p. 13. 
said, or even in the promise held forth of assisting in the solution of the malapportionment problem. Rather it lies in the far-reaching implications of the Supreme Court's action with respect to the function of law and legal institutions in modern American life. Essentially the decision marks a momentous step forward in utilizing law and legal principle for the maintenance and invigoration of the democratic structure of our society and in the assumption of a positive role by the Supreme Court in that task. In this respect the decision was indeed a "massive repudiation" of the school of thought of which Mr. Justice Frankfurter has been the intellectual and spiritual leader.

This is not to say that the Supreme Court has abandoned the time-honored forms of the judicial process. On the contrary, Mr. Justice Brennan's opinion is written entirely in terms of technical legal doctrine. To the man from Mars it would surely appear startling that a decision abruptly reversing the whole position of the Court on a vital and fundamental issue of substance should be couched exclusively as a discourse on abstract legalisms of jurisdiction, standing, justiciability and "political questions." Nowhere does Mr. Justice Brennan find it necessary to mention the actual facts or issues at the heart of the problem. Moreover, in the best tradition of the judicial process Mr. Justice Brennan carefully demonstrates that no change has occurred at all, that the outcome is wholly in line with, not to say compelled by, past precedents of the Court. And, again, the Court respects the judicial tradition by deciding only the narrowest possible issue, leaving development of the new area opened up by the decision to future elaboration on a case-by-case basis.

Nevertheless, the meaning of the Court's action is plain. As the nation has been transformed from a relatively individualistic to a highly organized society, and as industrialization, urbanization and bureaucratization have come to be the chief characteristics of the modern way of life, the part played by law and legal institutions in protecting the rights of the individual and maintaining the basic procedures of the democratic process has sharply altered. No longer are such rights and procedures the automatic by-product of economic and political laissez-faire. Their main support must rather rest upon a conscious growth of legal principles and institutions, designed to give strength and vitality to the ideals and mechanisms of democratic living.

The problem of malapportionment is one which peculiarly fits such a judicial role. For the usual methods by which a majority can constitutionally gain its ends are blocked. The issue thus goes deeper than the ordinary questions facing a democratically organized community. It raises a problem which is, in effect, anterior to the operation of the democratic process, namely the form and content of the basic political units which make up the system. The functioning of a democratic state assumes agreement upon this fundamental issue. When disagreement develops, apart from resolution by the judiciary, the only recourse is voluntary relinquishment of political power or recourse to extra-constitutional means. If the disagreement is irreconcilable the result is a break up of the structure in revolution, as happened in the Civil War or on a lesser scale 
in Dorr's Rebellion. Within the democratic structure it is primarily the courts which are in a sufficiently independent position to effect a rational, peaceful and constitutional solution. In terms of democratic theory, therefore, there are weighty reasons for the courts, despite the manifest difficulties, to utilize their prestige, powers and procedures in attempting to resolve questions of malapportionment.

Thus the decision in Baker v. Carr is wholly in line with the direction that the Supreme Court must take and, with some lapses to be sure, has been taking for the past quarter of a century. In the impetus given this crucial development lies the real significance of the decision. 